\title{
Crop Production Function for Chrysanthemum Crop under Drip Irrigation System
}

\author{
D. Jawaharlal*, M. Srinivasulu, G. Manoj Kumar and A. Manohar Rao \\ Department of Soil and Water Engineering, College of Agricultural Engineering, \\ Prof. Jayashankar Telangana State Agricultural University, Rajendranagar, Hyderabad, \\ Telangana, India \\ *Corresponding author
}

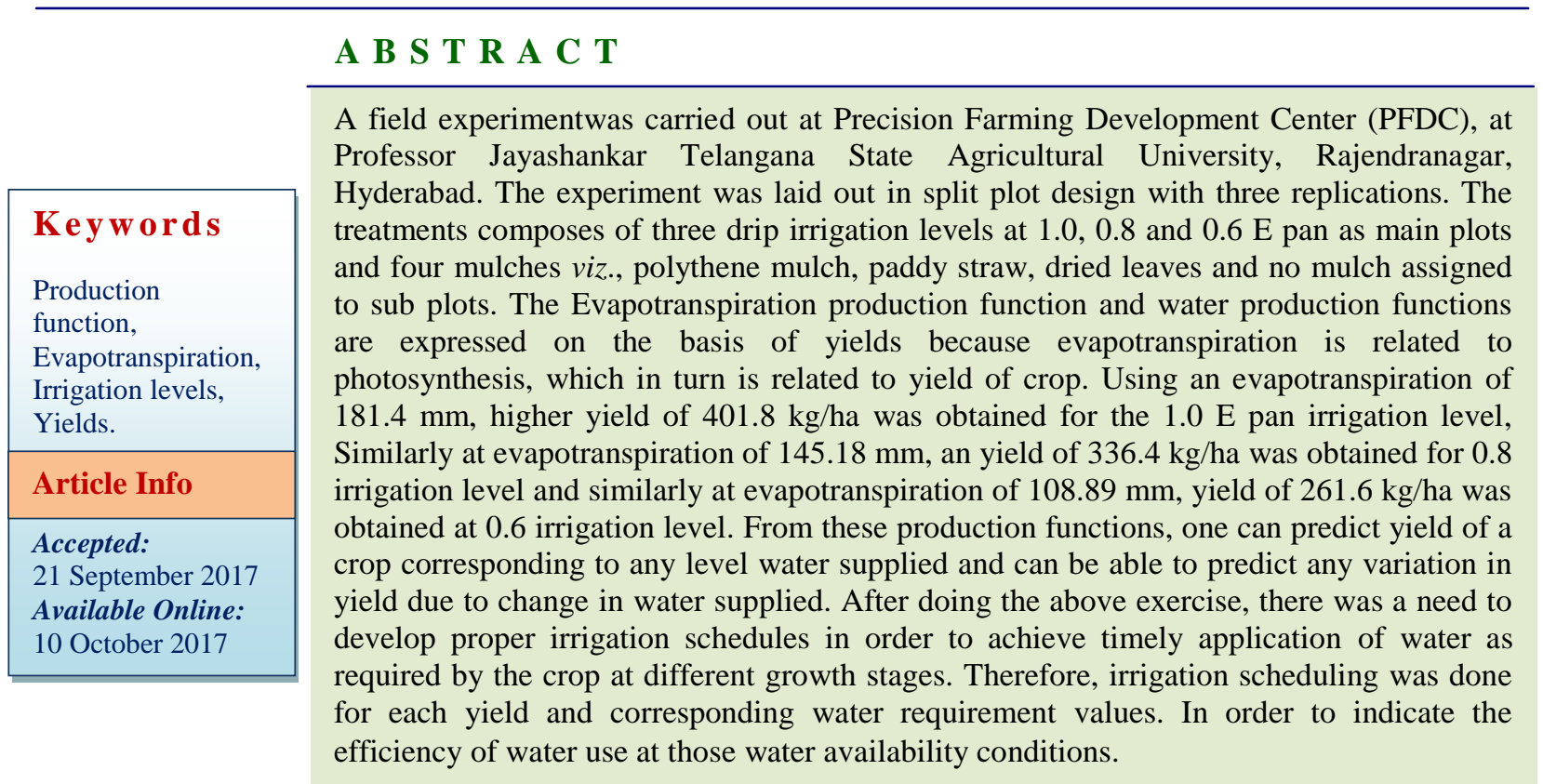

\section{Introduction}

Chrysanthemum being a shallow rooted flower crop, nutrition enrichment for the crop and the prevalence of congenial soil moisture and temperature are considered important for improved crop yield. Besides weed competition, evapotranspiration loss of moisture without proper supplement of irrigation impedes the economical productivity of the crop. Hence irrigation plays an important role on the crop production of chrysanthemum. The first extensive comparison of drip irrigation with conventional form of irrigation were made by Glodberg and his co-workers under severely limiting environmental conditions in the Arava and Negev districts of Israel and where an yield of more than 75 percent was observed in case of pepper, tomato crops (Goldberg and Shumeli, 1971a; Goldberg and Shumeli, 1971b). In view of deficit of water condition prevailing in the study area, there is a need to adopt micro irrigation to conserve the water in the soil profile and its best possible utilization for plant growth. Covering 
the gaps between the rows with mulch material prevent rapid evaporation from the soil surface and reduce rapid drying of the land. Mulching also suppress weed infestation effectively. Furthermore, it stimulates microbial activity in soil by increasing soil temperature, which improves agro physical properties of soil (Solaiman et al., 2008). Several research evidences on mulches in flower crops such as China aster, Cross and ray, Gladiolus and Marigold proved to be effective in preventing the loss of moisture (Solaiman et al., 2008, Murugan and Gopinath 2001, Barman et al., 2005, Gavhane et al., 2004). However, information on the effectiveness of using different mulches on growth and development of chrysanthemum to this region is not adequately available.

\section{Materials and Methods}

The experiment conducted in experimental field of Precision Farming Development Center, Institute of Agricultural Engineering and Technology, Prof. Jayashankar Telangana State Agricultural University, Rajendranagar, Hyderabad. Study area falls under arid subtropical climate zone with an average annual rainfall of $800 \mathrm{~mm}$, Soil samples were collected at random from 0 to $30 \mathrm{~cm}$ soil depth of field and were analyzed soil tests in the laboratory of Agricultural Research Institute of PJTS Agricultural University using the standard methodology, it reveals that the type of soil is sandy clay loam in texture, slightly alkaline nature and nonsaline. The infiltration rate was $2.3 \mathrm{~mm} / \mathrm{h}$ and hydraulic conductivity was $2.5 \mathrm{~mm} / \mathrm{h}$.

Moisture retention capacity of the experimental field was estimated at $0.01 \mathrm{MPaand}-1.5 \mathrm{MPa}$ using pressure membrane apparatus (Richards, 1949) and the bulk density of the experimental soil was estimated for each $15 \mathrm{~cm}$ soil depth up to 30 $\mathrm{cm}$ by following the standard procedures (Dastane, 1972) and the resultant data was presented in the below Table. The total available soil moisture i.e., the difference between $-0.1 \mathrm{MPa}$ and $1.5 \mathrm{MPa}$ in $0-30 \mathrm{~cm}$ soil depth was also estimated. The ground water table remained well below $6 \mathrm{~m}$ depth of soil during the course of investigation (as evident from the nearby open well) and it was assumed that it did not contribute to the crop water use.

Crop water production functions describe the relationship of crop yield (Y) response to varying levels of water input and can be useful for various water management applications. Many of the water production functions presented in the literature were developed relating yield to applied water, which usually includes irrigation water to satisfy crop water requirements in addition to rainfall and stored soil moisture prior to planting. Consequently, existing production functions based on applied water cannot often be routinely used crop water management outside of specific geographical locations, soil and water management conditions for which the data were developed.

One of the more useful and widely accepted production function forms is based on the consumptive use, or evapotranspiration (ET), of water as a yield index. For optimizing the water use for a given yield target, the relationship between the crop yield and water used must be known. The relationship between the yield and water used for raising the crop is termed as "production function". For successful crop production, crop must be supplied with adequate quantity of water at required frequency.

\section{Design and layout of the experiment}

The experiment was laid out using Split plot design with three replications. Three irrigation levels were taken as the main treatments and four mulches are taken as subtreatments. 


\section{Layout of the drip system}

Drip system consists of main, sub-main and laterals that were laid out in the experimental plot. The laterals of $12 \mathrm{~mm}$ diameter were laid $1.2 \mathrm{~m}$ apart with spacing of $45 \mathrm{~cm}$ distance between two inline emitters. The each emitter discharge capacity was $4 \mathrm{~L} / \mathrm{h}$.

\section{Reference crop evapotranspiration}

$\mathrm{ETo}=\mathrm{Kp} \times$ Epan

Where:

ETo $=$ Reference crop evapotranspiration (mm/day)

$\mathrm{Kp}=$ Pan coefficient

Epan $=$ Pan evaporation $(\mathrm{mm} /$ day $)$

\section{Crop evapotranspiration}

$\mathrm{ETc}=\mathrm{ETo} \times \mathrm{Kc}$

Where

$\mathrm{ETc}=$ Crop evapotranspiration $(\mathrm{mm} /$ day $)$

ETo $=$ Reference crop evapotranspiration (mm/day)

$\mathrm{Kc}=$ Crop coefficient

\section{Reference crop evapotranspiration [ET0]}

ET0 is a climatic parameter and can be computed from weather data. The ET0values are calculated using FAO CROPWAT model by giving the meteorological data and soil data as the input.ET0 expresses the evaporating power of the atmosphere at a specific location and time of the year and does not consider the crop characteristics and soil factors. Thus, in the present study the FAO Penman-Monteith method (Allen et al.,
1998), Modified Penman method and Adjusted Pan Evaporation method (Doorenbos and Pruitt, 1977) were used to determine ET0 as follows.

\section{Water use efficiency}

Water use efficiency (WUE) is the yield that can be produced from a given quantity of water. It was worked out by using the following formula and expressed as $\mathrm{kg}$ $\mathrm{ha} / \mathrm{mm}$.

\section{Results and Discussion}

The experiment included three levels of irrigation provided by drip irrigation. The each irrigation treatments was replicated three times and supplied with the same (nonlimiting) level of nutrients. Optimum cultivation practices were adopted in all the plots. Irrigation scheduling for the treatments were based on different levels of allowable soil water depletion in the crop root zone. Irrigation scheduling and Crop ET was determined by using Penman- montieth method and using FAO-CROPWAT model separately. Losses from surface water runoff were negligible and deep percolation was ignored. The production functions was developed between the crop evapotranspiration values in terms of $\mathrm{mm}$ and yield of the flowers, the production function was developed in excel software considering $\mathrm{X}$ values as input values and $\mathrm{Y}$ values as the output values. Overall crop production function and water production functions for different mulch conditions are depicted in Fig 52 -57. All the experiments were monitored under a single technical program in order to bring uniformity in the results. WPFs were developed for each mulch treatment by fitting the data into excel software. However, the best-fit function based on the maximum value of coefficient of correlation ' $\mathrm{R} 2$ ' was adjudged as per the required WPF for the crop. 
For chrysanthemum crop evapotranspiration verses yield and applied water verses yield are shown in above figures and $\mathrm{R}^{2}$ values are found as 0.9985 nearer to one. Comparing the total crop evapotranspiration on abscissa and yield on $\mathrm{Y}$ axis, the relation is assessed for chrysanthemum crop. The seasonal Evapotranspiration, calculated from the seasonal Kc, contains an evaporation component that varies between irrigation levels, times and locations and is depicted in Figures.

Fig.1 Crop evapotranspiration verses yield

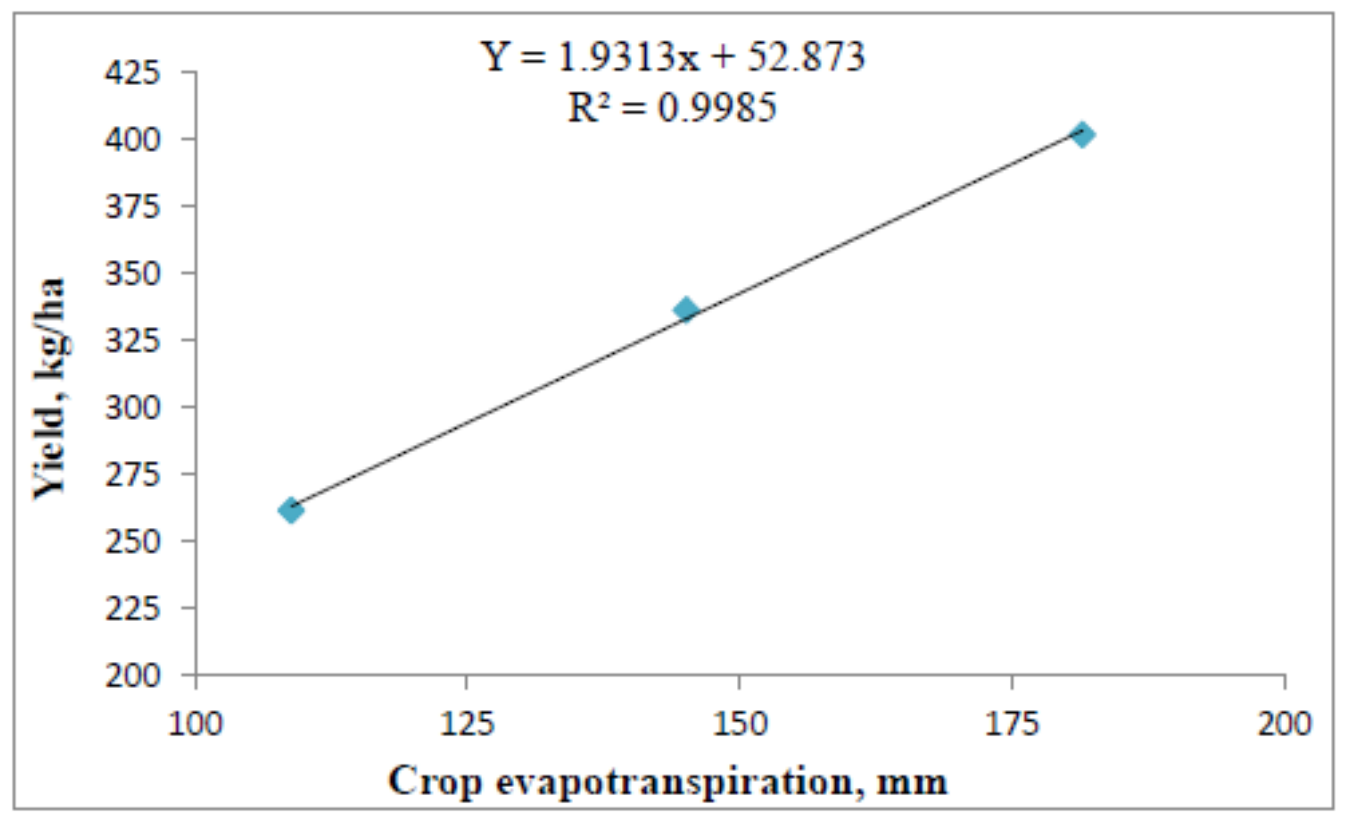

Fig.2 Applied water verses yield

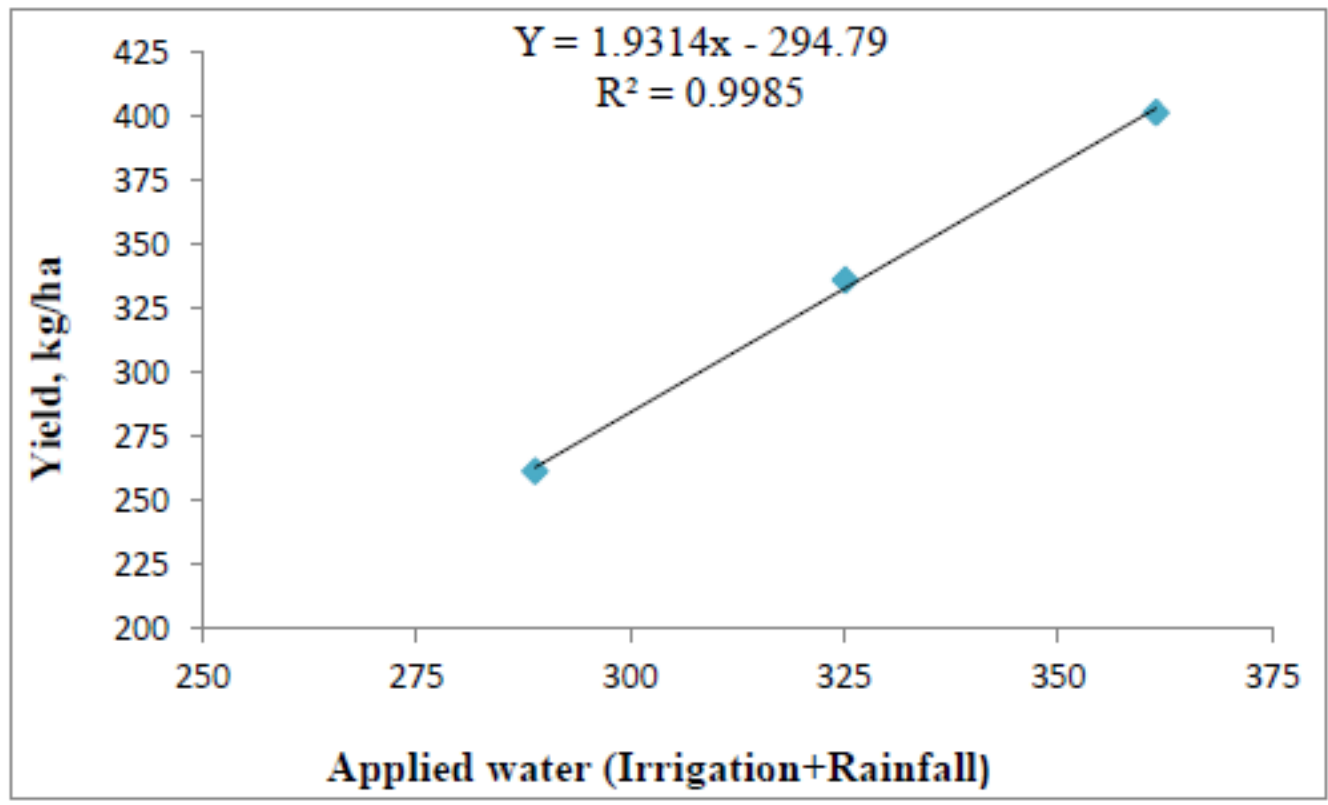


Fig.3 Crop evapotranspiration verses yield for no mulch

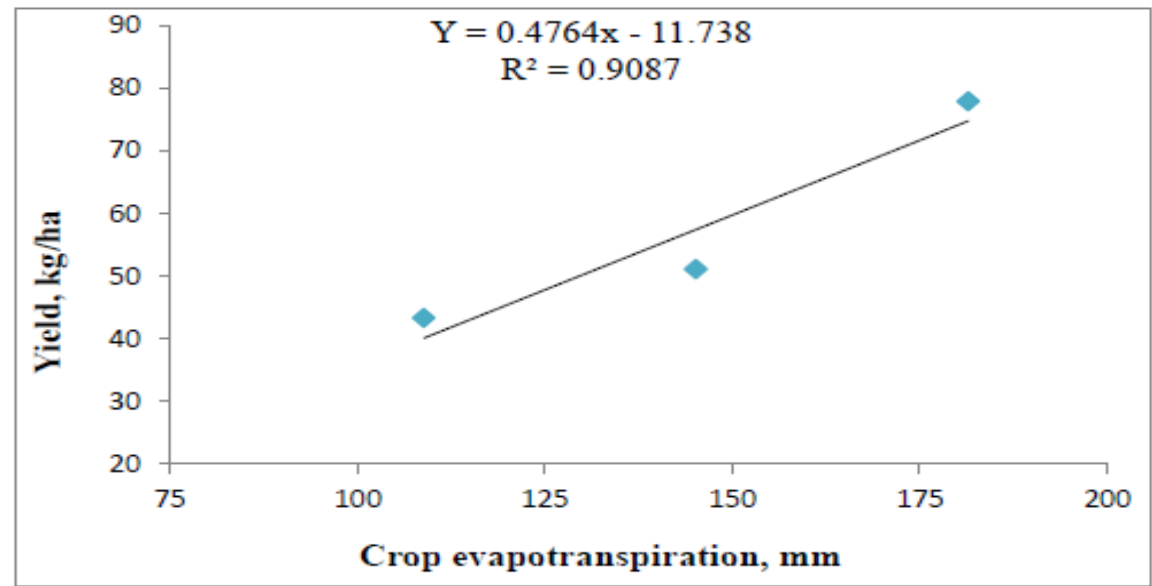

Fig.4 Crop evapotranspiration verses yield for paddy straw

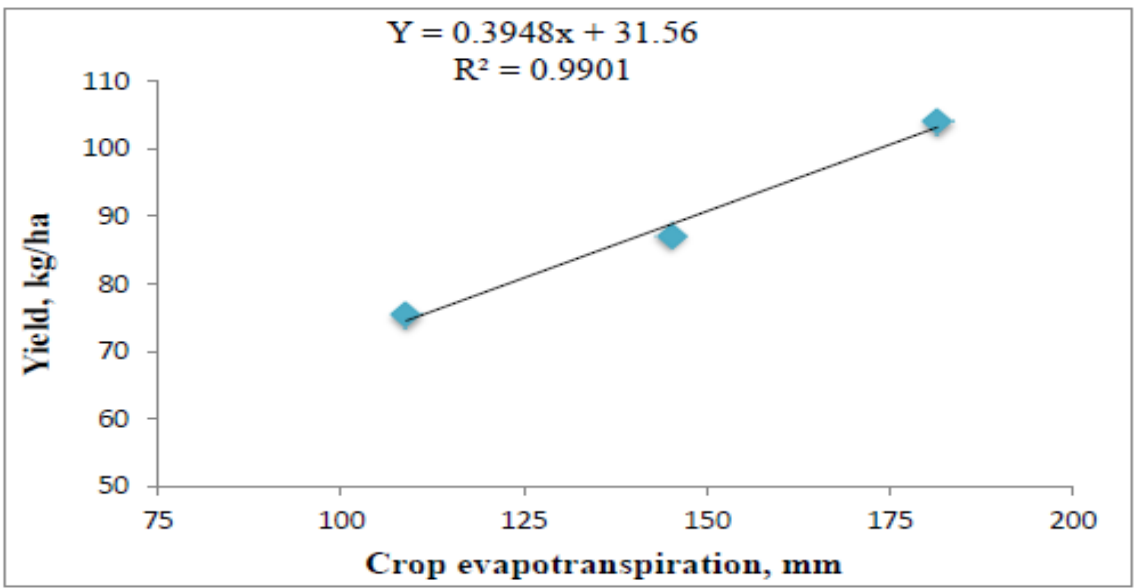

Fig.5 Crop evapotranspiration verses yield for black plastic mulch

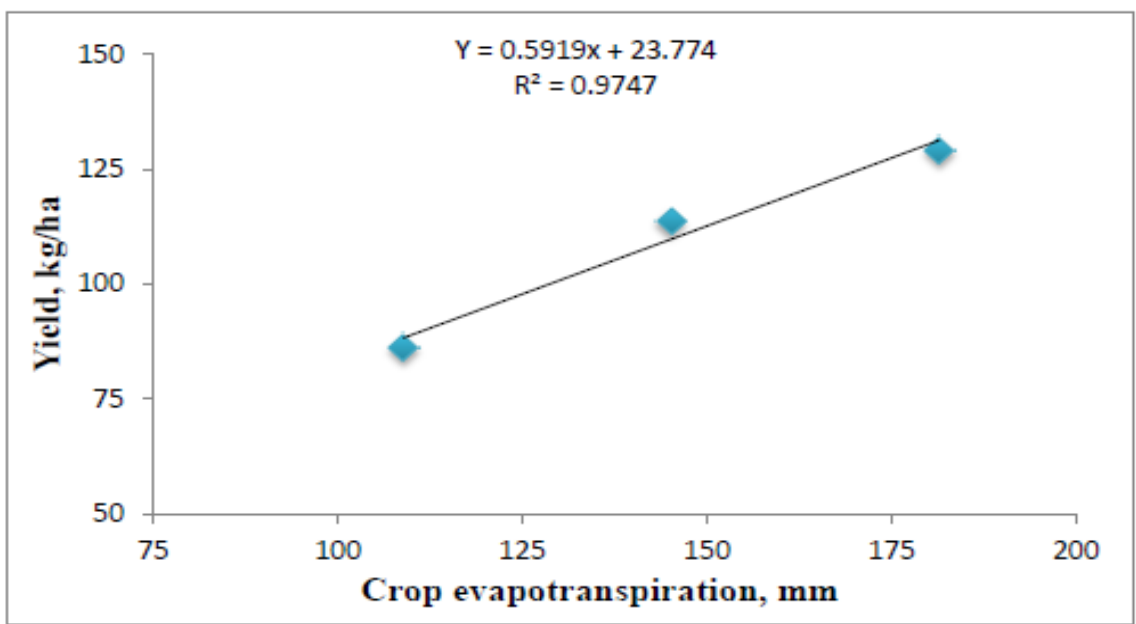


Fig.6 Crop evapotranspiration verses yield for dried leaves

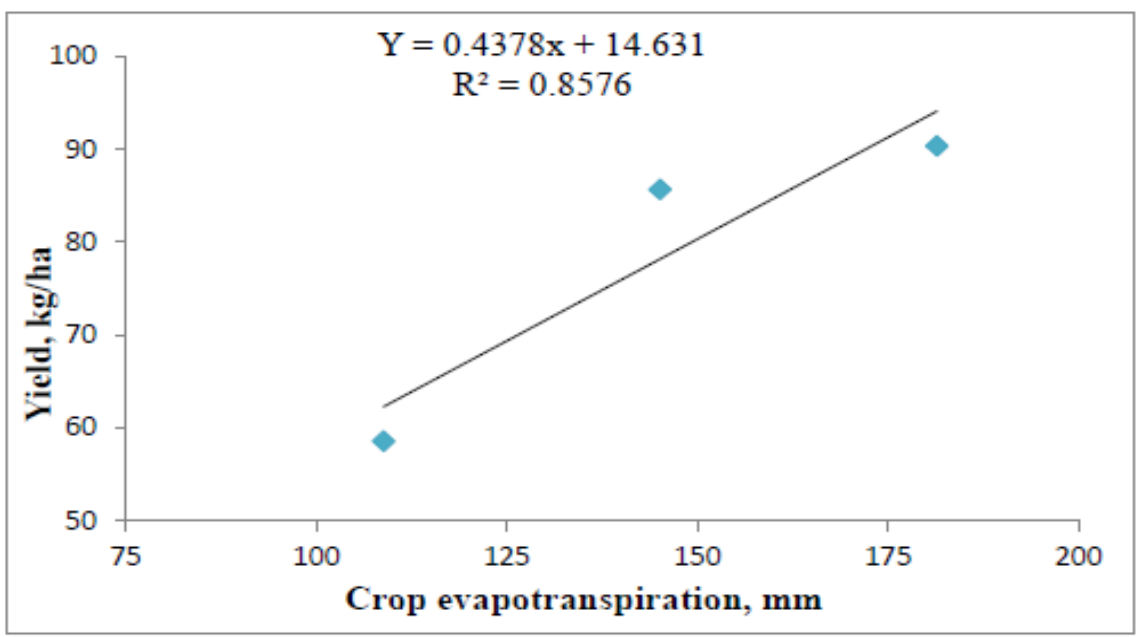

Table.1 Moisture retention characteristics of the experimental soil Soil depth $(\mathrm{cm})$

\begin{tabular}{|c|c|c|c|c|}
\hline \multirow{2}{*}{$\begin{array}{c}\text { Soil depth } \\
\text { (cm) }\end{array}$} & \multicolumn{2}{|c|}{ Soil moisture content (\%) at } & Bulk density \\
\cline { 2 - 5 } & $\begin{array}{c}\text { Field capacity } \\
{[-\mathbf{0 . 1} \text { MPa] }}\end{array}$ & $\begin{array}{c}\text { Permanent } \\
\text { Wiltingpoint } \\
{[-\mathbf{- 1 . 5 M P a}]}\end{array}$ & $\begin{array}{c}\text { Available soil } \\
\text { moisture } \\
\text { [mm] }\end{array}$ \\
\hline $0-15$ & 16.85 & 8.36 & 1.36 & 17.31 \\
\hline $15-30$ & 19.67 & 12.02 & 1.41 & 16.17 \\
\hline $30-45$ & 24.60 & 12.56 & 1.46 & 26.36 \\
\hline
\end{tabular}

The Evapotranspiration production function and water production functions are expressed on the basis of yields because evapotranspiration is related to photosynthesis, which in turn is related to yield of crop. Using an evapotranspiration of $181.4 \mathrm{~mm}$, higher yield of $401.8 \mathrm{~kg} / \mathrm{ha}$ was obtained for the $1.0 \mathrm{E}$ pan irrigation level, Similarly at evapotranspiration of $145.18 \mathrm{~mm}$, an yield of $336.4 \mathrm{~kg} / \mathrm{ha}$ was obtained for 0.8 irrigation level and similarly at evapotranspiration of $108.89 \mathrm{~mm}$, yield of $261.6 \mathrm{~kg} / \mathrm{ha}$ was obtained at 0.6 irrigation level. From these production functions, one can predict yield of a crop corresponding to any level water supplied and can be able to predict any variation in yield due to change in water supplied. Similarly it is made possible to assess the WUE in any particular situation. After doing the above exercise, there was a need to develop proper irrigation schedules in order to achieve timely application of water as required by the crop at different growth stages. Therefore, irrigation scheduling was done for each yield and corresponding water requirement values. In order to indicate the efficiency of water use at those water availability conditions, have been worked out.

The experiment was laid out in split plot design with three replications. The treatments composes of three drip irrigation levels at 1.0, 0.8 and $0.6 \mathrm{E}$ pan as main plots and four mulches viz., polythene mulch, paddy straw, dried leaves and no mulch assigned to sub plots.

The highest $R^{2}$ values are found for black plastic mulch and paddy straw conditions equation yield can adopt. 
Highest crop production function noticed for black plastic mulch and paddy straw for any irrigation levels highest yield found in black plastic and paddy straw mulches

\section{References}

Barman, D., Rajini K. Rampal and Upadhyaya. 2005. Effect of mulching on cut flower production and corn multiplication in gladiolus. The Journal of Orissa Horticulture 8 (2):152-154.

Gavhane, P. B., Kore V. N. Dixit A. J and Gondhali. 2004. Effect of graded doses of fertilizersand polythene mulches on Growth, Flower quality and Yield of marigold (Tagetus erecta) cv. Pusa Narangi Gainda. The Journal of Orissa Horticulture 32 (1): 35-37.

Goldberg, D., and Shumeli, M. 1971a.
Sprinkle and trickle irrigation of green pepper in an arid zone. Horticulture science. 6: 559-562.

Goldberg, D., and Shumeli, M. 1971b. The effect of distance from the trickles on soil salinity growth and yield of seed corn in arid zone. Horticulture science. 6: 565-567.

Murugan, M., and Gopinath G. 2001. Influence of mulches on quality, flower yield and economics of Crossandra. Crop Research. 22(2): 236-240.

Solaiman, A. H. M., Kabir M. H. Jamal Uddin A. F. M and Mirza Hasanuzzaman. 2008. Black Plastic Mulch on Flower Production and Petal Coloration of Aster. (Callistephus chinensis). American-Eurasian Journal of Botany 1 (1): 05-08.

\section{How to cite this article:}

Jawaharlal, D., M. Srinivasulu, G. Manoj Kumar and Manohar Rao, A. 2017. Crop Production Function for Chrysanthemum Crop under Drip Irrigation System. Int.J.Curr.Microbiol.App.Sci. 6(10): 2340-2346. doi: https://doi.org/10.20546/ijcmas.2017.610.276 